\title{
Inadequate corpus luteum function after the induction of ovulation in anoestrous ewes by LH-RH or an LH-RH agonist
}

\author{
A. S. McNeilly, Morag Hunter†, R. B. Land* and H. M. Fraser \\ M.R.C. Unit of Reproductive Biology, 37 Chalmers Street, Edinburgh EH3 9EW, and \\ *A.R.C. Animal Breeding Research Organisation, West Mains Road, Edinburgh EH9 3JQ, U.K.
}

\begin{abstract}
Summary. Scottish Blackface ewes were given LH-RH $(3 \times 30 \mu \mathrm{g}$ i.v., at $90 \mathrm{~min}$ intervals) or D-Ser-(But) ${ }^{6}$-des Gly ${ }^{10} \mathrm{LH}-\mathrm{RH}$ ethylamide (LH-RH agonist) as a single injection $(8$ or $40 \mu \mathrm{g})$ during anoestrus. Ovulation as judged by laparoscopy occurred in 8 of the 27 animals. Despite the fact that the LH-RH agonist induced a greater release of LH and FSH the different treatments had no effect on the number of ewes ovulating and within each treatment group there was no apparent difference in the amounts of gonadotrophins released between the ewes that did or did not ovulate. All ovulations resulted in the formation of CL associated with plasma progesterone concentrations of $<1 \mathrm{ng} / \mathrm{ml}(1-5 \mathrm{ng} / \mathrm{ml}$ in the normal luteal phase). In comparison with $\mathrm{CL}$ of the normal cycle the induced $\mathrm{CL}$ were of lower weight and had reduced progesterone content and ability to secrete progesterone in vitro. However, the binding of $\mathrm{hCG}$ was equivalent to that of normal $\mathrm{CL}$.

These results suggest that the inadequate CL formed in anoestrous ewes after a single LH-RH injection have not developed the ability to synthesize and secrete progesterone in spite of the presence of normal amounts of $\mathrm{LH}$ receptors.
\end{abstract}

\section{Introduction}

While ovulation can be induced by single or multiple injections or infusions of LH-RH in seasonally anoestrous ewes, the resulting corpus luteum (CL) fails to secrete amounts of progesterone comparable to those secreted by CL during the breeding season and is therefore considered to be inadequate (Crighton, Foster, Haresign \& Scott, 1975; Haresign, Foster, Haynes, Crighton \& Lamming, 1975; Shareha, Ward \& Birchall, 1976). Suppression of the elevated plasma levels of prolactin associated with anoestrus before induction of ovulation failed to alleviate this malfunction of the CL (McNeilly \& Land, 1979; Land, Carr, McNeilly \& Preece, 1980), although pretreatment of such ewes with PMSG was effective (Haresign \& Lamming, 1978). These results suggest that the failure of normal luteal function in anoestrous ewes is probably due to inadequate gonadotrophin priming of the follicle before the ovulatory LH surge (McNeilly, 1980).

Nevertheless, it has been reported that ovulation followed by normal CL function can be induced in anoestrous ewes by the injection of a highly potent agonist of LH-RH (Frandle et al., 1977). LH-RH agonists release a greater amount of FSH than does a single injection of LH-RH (Siddall \& Crighton, 1977) and this enhanced secretion of gonadotrophin might be sufficient to

\footnotetext{
$\dagger$ Present address: Department of Biochemistry, Royal Free Hospital, School of Medicine, London WC1N 1BP, U.K.
} 
prime the follicle before ovulation, thus allowing formation of a fully functional CL.

The present study was designed to compare CL function after ovulation had been induced by LH-RH or an LH-RH agonist. Since it was anticipated that ewes ovulating after treatment with LH-RH would have inadequate CL, the site of this inadequacy was investigated by comparing the ability of their $\mathrm{CL}$ to produce progesterone and bind $\mathrm{LH}$ in vitro with that of $\mathrm{CL}$ recovered from ewes during a normal oestrous cycle.

\section{Materials and Methods}

\section{Animals}

The experiment was carried out in July 1978. The 27 3- or 4-year-old Scottish Blackface ewes were maintained outdoors at pasture under natural lighting at the A.B.R.O. Dryden Field Laboratory. A vasectomized ram was introduced in May to check that they were anoestrous.

\section{LH-RH and LH-RH agonist treatments}

Ewes were randomly allocated to 3 groups ( 9 ewes in each) and on Day 0 were treated as follows: Group 1, 3 i.v. injections of $30 \mu \mathrm{g}$ synthetic LH-RH (Hoechst, Frankfurt, Germany) at 90-min intervals (10:00, 11:30 and 13:00 h); Group 2, a single i.v. injection (10:00 h) of $8 \mu \mathrm{g}$ synthetic D-Ser-(But) ${ }^{6}$-des Gly ${ }^{10}$ LH-RH ethylamide (LH-RH agonist, Hoechst); Group 3, a single i.v. injection (10:00 h) of $40 \mu \mathrm{g} \mathrm{LH}-\mathrm{RH}$ agonist.

\section{Blood sampling}

Daily jugular venous blood samples were taken from all animals at $09: 00 \mathrm{~h}$ on each of Days -5 to +18 . On Day 0 samples were collected at 30 -min intervals from $1 \mathrm{~h}$ before to $4 \mathrm{~h}$ after the first (Group 1) or only (Groups 2 and 3) injection and then every 1 or $2 \mathrm{~h}$ for a further $19 \mathrm{~h}$. Blood samples were collected into heparinized evacuated tubes, and the plasma was stored at $-20^{\circ} \mathrm{C}$ until assayed.

\section{Ovarian activity and collection of $C L$}

The ovaries of all ewes were examined by laparoscopy performed under barbiturate anaesthesia 6 days before and 5 days after LH-RH or agonist injection. The presence of a fresh (red) CL was taken as evidence of recent ovulation. The blood sample taken on the day of the second laparoscopy (Day +5$)$ was immediately assayed to check the progesterone secretory activity of the CL seen at laparoscopy. On Day +8 these $C L$ were removed surgically under anaesthesia induced by barbiturate and maintained by halothane from the 8 ewes that had ovulated: 7 ewes had $1 \mathrm{CL}$ each and 1 ewe had $2 \mathrm{CL}$.

After excision, each CL was trimmed of extraneous tissue, cut into pieces and weighed on a Torsion balance. Two pieces (10-200 mg depending on CL weight) were taken to estimate the binding of hCG and progesterone content, respectively; these were placed in plastic tubes, snap-frozen in a bath containing methanol and solid $\mathrm{CO}_{2}$ within 30 min of removal from the ovary and stored at $-20^{\circ} \mathrm{C}$ until analysis. The remaining pieces of $\mathrm{CL}$ were finely minced with two scalpel blades and washed in $50 \mathrm{ml}$ Eagle's minimum essential medium containing Hepes buffer and Earle's salts (pH 7.6; EMEM) before estimation of the progesterone secretory capacity of each CL. 
In-vitro production by and content of progesterone in $C L$

Equal amounts of minced luteal tissue (mean 16, range 10-27 mg in 0.1 ml EMEM) were incubated in replicate ( $n=2-6$ depending on the amount of CL mince available) in a final volume of $2 \mathrm{ml} \mathrm{EMEM}$ alone (basal) or containing 10 i.u. hCG (Pregnyl: Organon, Morden, Surrey, U.K.). After gassing with $95 \% \mathrm{O}_{2}, 5 \% \mathrm{CO}_{2}$ for $10 \mathrm{sec}$ the tubes were sealed with Parafilm (Gallenkamp) and incubated for $3 \mathrm{~h}$ at $37^{\circ} \mathrm{C}$ in a shaking water bath. After incubation, the CL mince and medium were separated by centrifugation at $600 \mathrm{~g}$, and the mince was homogenized in $4 \mathrm{ml}$ absolute ethanol for $1 \mathrm{~min}$ (I.L.A. Homogenizer, Type X10/20). The homogenate was then centrifuged and the supernatant decanted and stored at $-20^{\circ} \mathrm{C}$.

The initial progesterone content of the CL was assessed by extraction of duplicate amounts of $\mathrm{CL}$ mince before incubation. All samples were stored at $-20^{\circ} \mathrm{C}$ until assayed for progesterone.

Progesterone production throughout the incubation was calculated by subtracting the progesterone concentration in the tissue before incubation from the mean of the total progesterone in the medium plus tissue in each incubate after incubation.

\section{Binding of $h C G$ to $C L$}

The binding of hCG was assessed with the hCG preparation CR119 (NIH) labelled with ${ }^{125}$ I by the lactoperoxidase method (Miyachi, Vaitukaitis, Nieschlag \& Lipsett, 1972) as described in detail for human CL (McNeilly, Kerin, Swanston, Bramley \& Baird, 1980). Briefly, pieces of $\mathrm{CL}(10-200 \mathrm{mg})$ were homogenized $(1 / 5, \mathrm{w} / \mathrm{v})$ in $0.01 \mathrm{M}-$ Tris-HCl buffer, $\mathrm{pH} 7 \cdot 5$, containing $0.1 \%$ bovine serum albumin (BSA) at $4^{\circ} \mathrm{C}$ for $20 \mathrm{sec}$ with a Polytron (Kinematica, Lucerne, Switzerland) at half maximum speed. The homogenate was then centrifuged at $600 \mathrm{~g}$ for $1 \mathrm{~h}$ at $4^{\circ} \mathrm{C}$, the supernatant removed and the precipitate re-suspended in buffer to give a concentration of $10 \mathrm{mg} \mathrm{CL}$ tissue $/ \mathrm{ml}$.

To assess specific binding $0.1 \mathrm{ml}$ homogenate was placed in $7-\mathrm{ml}$ polystyrene tubes containing ${ }^{125} \mathrm{I}$-labelled hCG ( $2 \mathrm{ng}$ hormone) and $0.05 \mathrm{ml}$ buffer and incubated in triplicate for 3 $\mathrm{h}$ at $37^{\circ} \mathrm{C}$ with shaking.

Non-specific binding was assessed by the addition of 100 i.u. hCG (Pregnyl) to the buffer. Incubation was terminated by the addition of $3 \mathrm{ml}$ cold buffer and the tubes were centrifuged at $1500 \mathrm{~g}$ for $30 \mathrm{~min}$ at $4^{\circ} \mathrm{C}$. The supernatant was decanted and the precipitate counted in a well-type gamma counter (LKB Wallac, Bromma, Sweden). Specific binding was calculated in terms of pg hCG bound per mg CL tissue. All CL, including those of control sheep (see below), were processed at the same time.

\section{CL from normally cyclic sheep}

To allow comparison of the content and in-vitro production of progesterone and the binding of hCG to the CL collected after LH-RH treatment of anoestrous sheep, CL were removed on Days $5(n=6)$ and $14(n=5)$ of the normal oestrous cycle (November) (oestrus = Day 0$)$ from 10 Scottish Blackface ewes. Ovulation was synchronized by the i.m. injection of a potent analogue of prostaglandin F-2 $\alpha$ (100 $\mu \mathrm{g}$ i.m. cloprostenol) (ICI 80996: ICI, Macclesfield, Cheshire) and $\mathrm{CL}$ were removed and processed exactly as described above for those of anoestrous ewes.

\section{Hormone assays}

Prolactin, LH and FSH were measured in duplicate in specific double-antibody radioimmunoassays exactly as described in detail previously (McNeilly \& Andrews, 1974; McNeilly, McNeilly, Walton \& Cunningham, 1976; Martensz, Baird, Scaramuzzi \& Van Look, 1976). The 
sensitivities of the assays were $0.5 \mathrm{ng}$ prolactin (NIH-P-S6)/ml, $0.1 \mathrm{ng} \mathrm{LH}(\mathrm{NIH}-\mathrm{LH}-\mathrm{S} 14) / \mathrm{ml}$ and $8 \mathrm{ng}$ FSH (NIH-FSH-S10)/ml. The intra- and interassay variations, as coefficients of variation, were 7 and $9 \%, 9.5$ and $12 \%$ and 8 and $11 \%$ for prolactin, FSH and LH respectively.

The progesterone concentrations in plasma, extracts of corpus luteum and culture media were measured by a specific radioimmunoassay described previously for plasma (Scaramuzzi, Corker, Young \& Baird, 1974). This assay has been validated for the measurement of progesterone in CL extracts (Swanston, McNatty \& Baird, 1977; McNeilly et al., 1980) and culture medium without extraction (Hunter, 1980). Intra- and interassay coefficients of variation (\%) were 6 and $10 \%$ respectively with a sensitivity of $0.1 \mathrm{ng} / \mathrm{ml}$.

\section{Statistical analysis}

Results were analysed by Student's $t$ test or analysis of variance.

\section{Results}

\section{Ovulation}

Ovulation was induced in 8 of the 27 ewes as judged by laparoscopy on Day 5 after treatment. The numbers of animals ovulating in each group were: LH-RH, 3/9; LH-RH agonist $8 \mu \mathrm{g}, 2 / 9: \mathrm{LH}-\mathrm{RH}$ agonist $40 \mu \mathrm{g}, 3 / 9$.

\section{Plasma hormone concentrations}

$L H$. After the first injection of LH-RH there was an initial increment of $5-33 \mathrm{ng} / \mathrm{ml}$ (Text-fig. 1) by $30 \mathrm{~min}$. This was followed by a much greater increment of $15-75 \mathrm{ng} / \mathrm{ml} 30 \mathrm{~min}$

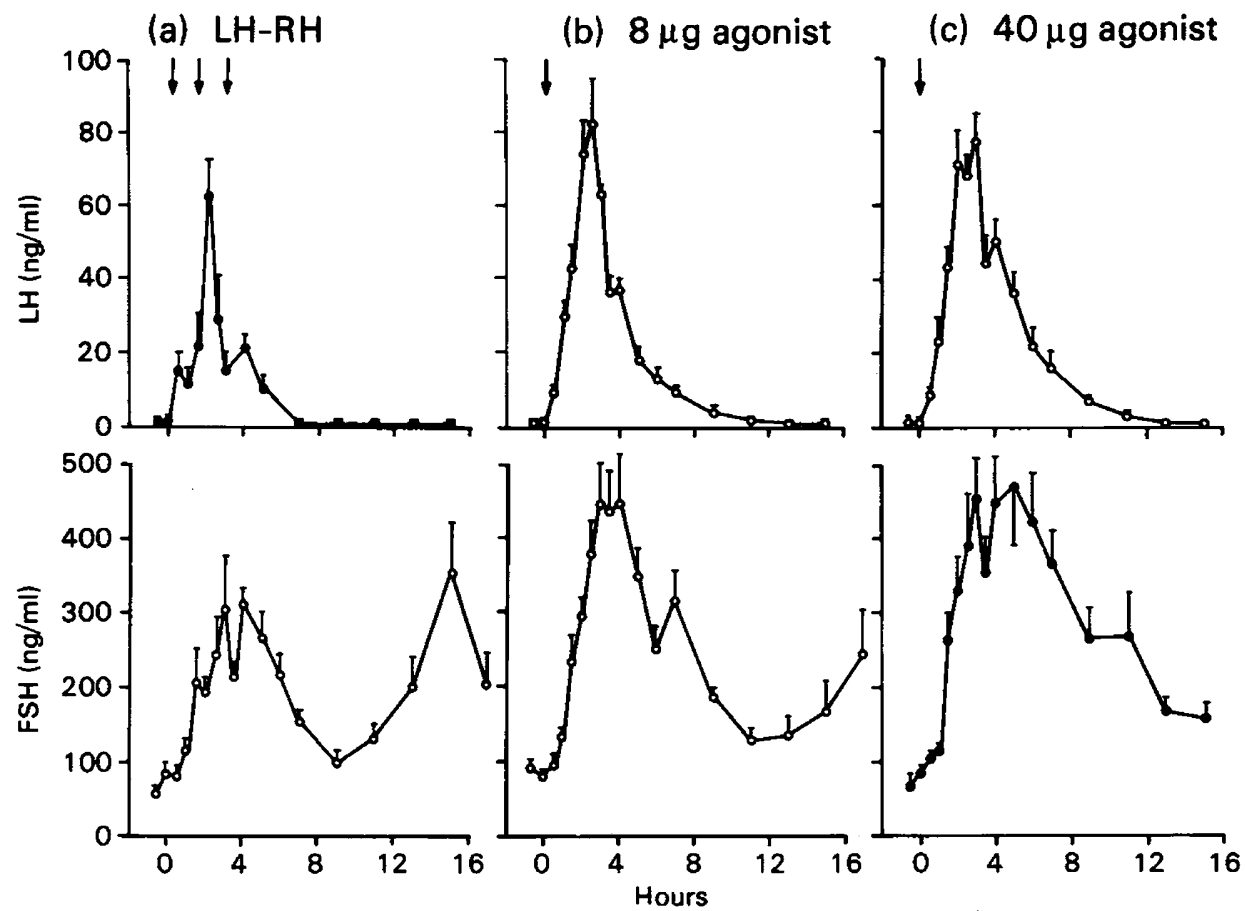

Text-fig. 1. Changes in the mean \pm s.e.m. plasma concentrations of LH and FSH in anoestrous ewes after i.v. injection (arrows) of (a) LH-RH (30 $\mu \mathrm{g}$ at 90-min intervals) or LH-RH agonist at doses of $8 \mu \mathrm{g}$ (b) or $40 \mu \mathrm{g}$ (c). 
after the second injection while there was little or no further change after the third injection. In contrast, after injection of LH-RH agonist plasma levels of LH increased steadily to mean (range) peak values of $92(49-158)$ and $83(50-122) \mathrm{ng} / \mathrm{ml}$ for 8 and $40 \mu \mathrm{g} \mathrm{LH}-\mathrm{RH}$ agonist respectively, the peaks occurring between 2 and $4 \mathrm{~h}$ after injection (Text-fig. 1).

Over the $21 \mathrm{~h}$ after injection of LH-RH or agonist there was no significant difference in the cumulative amount of $\mathrm{LH}$ released between the 2 doses of agonist (Table 1) but both doses of agonist released significantly greater amounts $(P<0.01)$ of LH than did LH-RH. There was no difference between the amounts of $\mathrm{LH}$ released in animals which did and those that did not ovulate in each treatment group (Table 1).

Table 1. The release of $\mathrm{LH}$ and FSH (as cumulative totals) after the injection of anoestrous ewes with LH-RH $(3 \times 30 \mu \mathrm{g})$ or LH-RH agonist $(8$ or $40 \mu \mathrm{g})$

\begin{tabular}{|c|c|c|c|c|c|}
\hline \multirow[b]{3}{*}{ Treatment } & \multirow{3}{*}{$\begin{array}{l}\text { No. of } \\
\text { ewes }\end{array}$} & \multicolumn{4}{|c|}{ Cumulative release $(\mathrm{ng} / \mathrm{ml})$} \\
\hline & & \multirow{2}{*}{$\begin{array}{c}\mathrm{LH} \\
(0-21 \mathrm{~h})\end{array}$} & \multicolumn{3}{|c|}{ FSH } \\
\hline & & & $0-7 \mathrm{~h}$ & $8-21 \mathrm{~h}$ & $0-21 \mathrm{~h}$ \\
\hline \multicolumn{6}{|l|}{$L H-R H$} \\
\hline All ewes & 9 & $196 \pm 40$ & $2322 \pm 245$ & $1455 \pm 218$ & $3777 \pm 425$ \\
\hline Ovulating ewes & 3 & $170 \pm 30$ & & & $3775 \pm 560$ \\
\hline Non-ovulating ewes & 6 & $168 \pm 22$ & & & $3778 \pm 572$ \\
\hline \multicolumn{6}{|l|}{ Agonist, $8 \mu \mathrm{g}$} \\
\hline All ewes & 9 & $365 \pm 36^{*}$ & $3377 \pm 230^{*}$ & $1354 \pm 135$ & $4730+318$ \\
\hline Ovulating ewes & 2 & 548,229 & & & 6087,3751 \\
\hline Non-ovulating ewes & 7 & $358 \pm 33$ & & & $4676 \pm 330$ \\
\hline \multicolumn{6}{|l|}{ Agonist, $40 \mu \mathrm{g}$} \\
\hline All ewes & 9 & $395 \pm 120^{*}$ & $3771 \pm 362^{*}$ & $1385 \pm 140$ & $5156 \pm 467$ \\
\hline Ovulating ewes & 3 & $407 \pm 78$ & & & $4622 \pm 478$ \\
\hline Non-ovulating ewes & 6 & $390 \pm 46$ & & & $5423 \pm 561$ \\
\hline
\end{tabular}

Values are mean \pm s.e.m. Times are relative to first injection of LH-RH or agonist $(0 \mathrm{~h})$.

* $P<0.01$ compared with value for LH-RH treated ewes (Student's $t$ test).

FSH. All animals showed an initial peak response in plasma levels of FSH between 90 min and $4 \mathrm{~h}$ after injection of LH-RH or LH-RH agonist and another peak 9-21 h later (Text-fig. 1). The time to this second peak was most variable $(9-17 \mathrm{~h})$ in ewes injected with the high dose (40 $\mu \mathrm{g})$ of LH-RH agonist and because of this variation a second peak is not apparent when mean values are taken. While there was an increase in the cumulative amount of FSH released over a 21-h period following injection of LH-RH agonist compared to $\mathrm{LH}-\mathrm{RH}$, this was not significant $(P=0.1$; Table 1). However, significantly more $(P<0.01)$ FSH was released in the initial response period $(0-7 \mathrm{~h})$ after both doses of LH-RH agonist than after LH-RH although there was no difference between the two agonist groups or in the amount of FSH released during the second response period $(8-21 \mathrm{~h})$ in any of the groups (Table 1). Within each treatment the initial cumulative FSH response $(0-7 \mathrm{~h})$ was significantly correlated with the basal plasma levels of FSH before treatment (LH-RH: $r=0.74, n=9$; LH-RH agonist $8 \mu \mathrm{g}: r=0.72, n=9$; LH-RH agonist $40 \mu \mathrm{g}: r=0.84 ; n=9$ ).

There was no difference in basal levels of FSH in the 4 days before treatment or in the response to LH-RH or LH-RH agonist in animals that did or did not ovulate.

Prolactin. In all anoestrous ewes prolactin values ranged between 56 and $230 \mathrm{ng} / \mathrm{ml}$ and none of the treatments affected these levels. During the normal luteal phase concentrations were $3-12 \mathrm{ng} / \mathrm{ml}$ and were significantly lower $(P<0.001)$ than during anoestrus.

Progesterone. In the animals that did not ovulate all values remained $<0.2 \mathrm{ng} / \mathrm{ml}$ regardless of treatment. In the animals that ovulated in each treatment group, progesterone concentrations 
rose normally during the first 3 days after ovulation but then started to decline. Levels were significantly lower $(P<0.01)$ on Day 8 than on Days 5 or 14 of the normal cycle (Table 2$)$. Values on Day 14 were significantly greater $(P<0.01)$ than on Day 5 (Table 2).

Table 2. Characteristics of corpora lutea collected during a normal oestrous cycle and 6 days after ovulation induced in anoestrus by LH-RH or LH-RH agonist

\begin{tabular}{|c|c|c|c|c|c|c|c|c|c|}
\hline \multirow[b]{3}{*}{ CL } & \multirow{3}{*}{$\begin{array}{l}\text { No. of } \\
\text { ewes }\end{array}$} & \multirow{3}{*}{$\begin{array}{l}\text { No. of } \\
\text { CL }\end{array}$} & \multirow{3}{*}{$\begin{array}{c}\text { Plasma } \\
\text { progesterone } \\
(\mathrm{ng} / \mathrm{ml})\end{array}$} & \multirow{3}{*}{$\begin{array}{l}\mathrm{Wt} \\
(\mathrm{mg})\end{array}$} & \multicolumn{5}{|c|}{ Corpus luteum } \\
\hline & & & & & \multirow{2}{*}{$\begin{array}{l}\text { Progesterone } \\
\text { content } \\
(\mathrm{ng} / \mathrm{ml})\end{array}$} & \multirow{2}{*}{$\begin{array}{c}\text { hCG } \\
\text { binding } \\
\text { (pg/ml) }\end{array}$} & \multicolumn{3}{|c|}{$\begin{array}{l}\text { Progesterone production in vitro } \\
(\mathrm{ng} / \mathrm{mg} / 3 \mathrm{~h})\end{array}$} \\
\hline & & & & & & & Basal & $+h C G$ & Increment \\
\hline \multicolumn{10}{|c|}{ Normal cycle } \\
\hline Day 5 & 6 & 6 & $1.25 \pm 0.35$ & $174 \pm 25$ & $5.7 \pm 0.7$ & $19.7 \pm 5.1$ & $29.6 \pm 3.6$ & $55.0 \pm 7.4$ & $25.4 \pm 5.9$ \\
\hline Day 14 & 5 & 6 & $4.49 \pm 0.80$ & $379 \pm 54$ & $11.8 \pm 0.5$ & $46.9 \pm 8.0$ & $42 \cdot 1 \pm 4 \cdot 1$ & $58.4 \pm 4.7$ & $16 \cdot 2 \pm 5 \cdot 6$ \\
\hline Anoestrus & 8 & 9 & $0.65 \pm 0.07$ & $90 \pm 12$ & $1.0 \pm 0.2$ & $29.4 \pm 8.9$ & $1.9 \pm 0.7$ & $2.7 \pm 1.2$ & $1.0 \pm 0.5$ \\
\hline
\end{tabular}

Values are mean \pm s.e.m.

Luteal progesterone secretion in vitro and $h C G$ binding. The weight and progesterone content of the CL increased significantly $(P<0.02$ to $P<0.001)$ between Days 5 and 14 of the normal cycle and values on both days were significantly greater $(P<0.01$ to $P<0.001)$ than those for the CL induced during anoestrus (Table 2).

The basal production of progesterone in vitro was significantly greater $(P<0.05)$ on Day 14 than Day 5 and values on these days were greater $(P<0.001)$ than that for the CL induced during anoestrus. hCG caused a significant increase in progesterone production from Day -5 ( $P$ $<0.02)$ and Day $-14(P<0.05) \mathrm{CL}$ of the cycle but not from CL induced during anoestrus (Table 2).

The binding of hCG increased significantly $(P<0.02)$ between Days 5 and 14 of the cycle, but binding was not significantly different at either stage from that of the CL of anoestrus (Table 2).

\section{Discussion}

The present results confirm previous observations (Crighton, Foster, Haresign, Haynes \& Lamming, 1973; Crighton et al., 1975; Haresign et al., 1975; McNeilly \& Land, 1979) that treatment of anoestrous ewes with single injections of LH-RH induces ovulation in approximately 1 animal in 4 but that the resulting corpus luteum produces less progesterone than does the CL of a normal cycle.

It has been suggested (Crighton et al., 1975; Frandle et al., 1977) that poor CL function after LH-RH treatment of anoestrous ewes was due to release of reduced amounts of LH before ovulation. However, in the present study, the injection of LH-RH agonist resulted in a release of both LH and FSH which was of similar or greater magnitude and duration to that occurring before ovulation in the normal oestrous cycle in the Scottish Blackface ewe (A. S. McNeilly, unpublished observations), and in Clun Forest ewes (Siddail \& Crighton, 1977). This suggests that reduced release of $\mathrm{LH}$ or FSH is not the primary cause of the inadequate CL.

The failure of normal CL function after LH-RH agonist injection in the present study contrasts with the results of Frandle et al. (1977) who induced ovulation in 8 of 13 anoestrous ewes given a single injection of LH-RH agonist and produced luteal phases similar to those of the natural cycle. The difference in results is not likely to be due to differences in the amounts of gonadotrophin release induced by the agonist since the $40 \mu \mathrm{g}$ dose of D-Ser-(But) ${ }^{6}$-des Gly ${ }^{10}$ LH-RH ethylamide used in the present study should be as active as $100 \mu \mathrm{g}$ of the less potent 
D-leu ${ }^{6}$-des Gly ${ }^{10}$ LH-RH ethylamide used by Frandle et al. (1977) (Sandow, König, Geiger, Uhmann \& von Rechenberg, 1978). Also, in the present study the incidence of ovulation did not appear to be influenced by the amount of LH and FSH released, and, since the CL function of the ewes that did ovulate was inadequate, it seems that the changes within the follicle which occur prior to ovulation as a prerequisite for a normal luteal phase are not induced by the LH or FSH surge alone. A period of suitable priming must therefore be required and it is unlikely that single injections of LH-RH agonist will be useful for inducing the formation of normal CL in anoestrous ewes without pretreatment. It may be that the ewes of mixed genetic background studied by Frandle et al. (1977) were at a more advanced stage of follicular development than were the Scottish Blackface ewes used in the present investigation.

Our results go some way to answer the question of why CL induced by LH-RH or its agonists are unable to produce much progesterone. While the CL taken during the normal cycle showed changes in weight and steroid content and were able to bind hCG and produce progesterone in vitro as expected (Diekman, O'Callaghan, Nett \& Niswender, 1978; Sawyer, Abel, McClellan, Schmitz \& Niswender, 1979), the CL taken 5 days after ovulation had been induced with LH-RH in anoestrous ewes were of reduced weight, had greatly reduced progesterone content and a negligible ability to produce progesterone in vitro, even after stimulation with hCG (Table 2). The plasma progesterone concentrations in these ewes were low when the corpora lutea were removed, but the binding of hCG to the luteal tissue was within the range seen during the normal luteal phase. These observations suggest that the formation of LH receptors on granulosa cells of the ovine CL are largely independent of the development of the ability to secrete progesterone. They also indicate that, even if plasma LH concentrations were raised in vivo after ovulation, the CL could not respond. The increased number of receptors for LH appears to be the major factor in the regulation of progesterone secretion by the corpus luteum (Diekman et al., 1978) but our results suggest that there may not be a simple relationship between the binding of $\mathrm{LH}$ to lutein cells and the secretion of progesterone.

\section{References}

Crighton, D.B., Foster, J.P., Haresign, W., Haynes, N.B. \& Lamming, G.E. (1973) The effects of a synthetic preparation of gonadotrophin releasing factor on pituitary and ovarian function in anoestrous ewes. $J$. Physiol., Lond. 231, 98P-99P.

Crighton, D.B., Foster, J.P., Haresign, W. \& Scott, S.A. (1975) Plasma and progesterone levels after single or multiple injections of synthetic LH-RH in anoestrous ewes and a comparison with levels during the anoestrous cycle. J. Reprod. Fert. 44, 121-124.

Diekman, M.A., O'Callaghan, P., Nett, T.M. \& Niswender, G.D. (1978) Vatidation of methods and quantification of luteal receptors for $\mathrm{LH}$ throughout the estrous cycle and early pregnancy in ewes. Biol. Reprod. 19, 999-1009.

Frandle, K.A., Kinder, J.E., Coy, D.H., Schally, A.V., Reeves, J.J. \& Estergreen, V.L. (1977) Plasma progestins in anestrous ewes treated with D-leu ${ }^{6}$ Des GlyNH $_{2}{ }^{10}$-LHRH ethylamide. J. A nim. Sci. 46, 486-491.

Haresign, W. \& Lamming, G.E. (1978) Comparison of $\mathrm{LH}$ release and luteal function in cyclic and LH-RH treated anoestrous ewes pretreated with PMSG or oestrogen. J. Reprod. Fert. 52, 349-353.

Haresign, W., Foster, J.P., Haynes, N.B., Crighton, D.B. \& Lamming, G.E. (1975) Progesterone levels following treatment of seasonally anoestrous ewes with synthetic LH-releasing hormone. J. Reprod. Fert. 43, 269-279.

Hunter, M.G. (1980) Studies on the corpus luteum in vitro. Ph.D. thesis, University of Edinburgh.

Land, R.B., Carr, W.R., McNeilly, A.S. \& Preece, R.D. (1980) Plasma FSH, LH, the positive feedback of oestrogen, ovulation and luteal function in the ewe given bromocriptine to suppress prolactin during seasonal anoestrus. J. Reprod. Fert. 59, 73-78.

Martensz, N.D., Baird, D.T., Scaramuzzi, R.J. \& Van Look, P.F. (1976) Androstenedione and the control of luteinizing hormone in the ewe during anoestrus. $J$. Endocr. 69, 227-237.

McNeilly, A.S. (1980) Paradoxical prolactin. Nature, Lond. 184, 212.

MeNeilly, A.S. \& Andrews, P. (1974) Purification and characterization of caprine prolactin. J. Endocr. 60 , 359-367.

McNeilly, A.S. \& Land, R.B. (1979) Effect of suppression of plasma prolactin on ovulation, plasma gonadotrophins and corpus luteum function in LH-RH-treated anoestrous ewes. J. Reprod. Fert. 56, 601-609.

MeNeilly, A.S., Kerin, J., Swanston, I.A., Bramley, T.A. \& Baird, D.T. (1980) Changes in the binding of human chorionic gonadotrophin/luteinizing hormone, follicle-stimulating hormone and prolactin to 
human corpora lutea during the menstrual cycle and pregnancy. J. Endocr. 87, 315-325.

McNeilly, J.R., McNeilly, A.S., Walton, J.S. \& Cunningham, F.J. (1976) Development and application of a heterologous radioimmunoassay for ovine follicle-stimulating hormone. J. Endocr. 70, 69-79.

Miyachi, Y., Vaitukaitis, J.L., Nieschlag, E. \& Lipsett, M.B. (1972) Enzymatic radioiodination of gonadotropins. J. clin. Endocr. Metab. 34, 23-28

Sandow, J., König, W., Geiger, R., Uhmann, R. \& von Rechenberg, W. (1978) Structure-activity relationships in the LH-RH molecule. In Control of Ovulation, pp. 49-70. Eds D. B. Crighton, G. R. Foxcroft, N. B. Haynes \& G. E. Lamming. Butterworth, London.

Sawyer, H.R., Abel, J.H. Jr., MeClellan, M.C., Schmitz, M. Niswender, G.D. (1979) Secretory granules and progesterone secretion by ovine corpora lutea in vitro. Endocrinology 104, 476-486.
Scaramuzzi, R.J., Corker, C.S., Young, G. \& Baird, D.T. (1974) Production of antisera to steroid hormones in sheep. In Steroid Immunoassay, pp. 111-122. Eds E. H. D. Cameron, S. G. Hillier \& K. Griffiths. Alpha Omega Alpha, Cardiff.

Shareha, A.M., Ward, W.R. \& Btrchall, K. (1976) Effects of continuous infusion of gonadotrophinreleasing hormone in ewes at different times of the year. J. Reprod. Fert. 46, 331-340.

Siddall, B. \& Crighton, D.B. (1977) Effects of certain analogues of synthetic luteinizing hormone releasing hormone on the release of luteinizing hormone and follicle-stimulating hormone in the anoestrous ewe. $J$. Endocr. 75, 49-57.

Swanston, I.A., MeNatty, K.P. \& Baird, D.T. (1977) Concentration of prostaglandin $F_{2 \alpha}$ and steroids in the human corpus luteum. J. Endocr. 75, 115-122.

Received 10 November 1980 